\title{
GELLÉRFI GERGŐ
}

\section{Elhagyom a várost! \\ Iuvenalis 3. szatírájának fordítása ${ }^{1}$}

Mindmáig az utolsó magyar Iuvenalis-fordítás 1964-ben jelent meg: a Horváth István Károly kiváló bevezető tanulmányával ellátott kiadás Muraközy Gyula magyarra átültetett szövegeit tartalmazza. ${ }^{2}$ A fordító meglehetősen jól adja vissza a szatírák hangulatát és Iuvenalis üzenetét, de a metrum jelentette kötöttségek helyenként olyan tömörítésekre, illetve megfogalmazásokra kényszerítik, melyek olykor már az érthetőség rovására mennek, megtörik a szöveg ritmusát, gördülékenységét, illetve kényszerü stiláris változásokat idéznek elő, az elkerülhetetlennél jobban eltávolítva a latin eredetitől a magyar fordítást.

Aligha véletlen, hogy azon nyelvek esetében (mint például az angol és a francia), ahol problematikus a hexameter - és más időmértékes metrumok - használata, a verses szövegek prózai fordítása már régóta bevett gyakorlatnak számít, elég csak a Loeb- vagy a Budé-sorozatokra gondolnunk. Az eredeti metrumot megőrző verses fordításokat illetően a magyar fordítók szerencsés helyzetben vannak, hiszen nyelvünk alapvetően alkalmas a hexameteres versmérték alkalmazására. Meggyőződésem azonban, hogy ennek ellenére a magyar prózai átültetéseknek is van létjogosultsága a verses fordítások mellett, hiszen a forrásnyelvet nem ismerő olvasók így kaphatják az eredetihez tartalmilag a legközelebb álló szövegeket kezükbe.

\footnotetext{
${ }^{1}$ A publikáció az MTA-SZTE Antikvitás és Reneszánsz: Források és Recepció Kutatócsoport (TK2016-126) és a Bolyai János Kutatási Ösztöndíj támogatásával készült.

2 MuRAKÖZY (1964).
} 
A következőkben olvasható fordítás voltaképpen egy kísérlet a tartalmi és stiláris szempontból lehető legpontosabb magyar Iuvenalisszöveg létrehozására. A választott költemény a 3. szatíra, melynek különlegessége nem csupán abból fakad, hogy vers legnagyobb részében nem a narrátor, hanem fiktív beszélgetőpartnere, egy Umbriciusnak nevezett interlocutor szavait olvashatjuk, hanem abból is, hogy a költőre olyannyira jellemző intertextuális játék ebben a versben a legerőteljesebb: a szatíra keretében bukolikus színezet fedezhető fel, Umbricius beszédét pedig Martialistól jól ismert témák (s olykor kifejezések), valamint epikus képek és allúziók szövik át. ${ }^{3}$ A vers utóélete is jelentős, különösen fontos Samuel Johnson a 3. szatíra nyomán írt London címü költeménye.

A vers központi karaktere a várostól megcsömörlött, otthonát részint annak erkölcsi romlása, részint saját sikertelensége okán hátrahagyó Umbricius. A narrátor egy megszentségtelenített locus amoenusban búcsúzik egy megfáradt, megkeseredett, a kor viszonyaihoz alkalmazkodni képtelen (s talán nem is akaró) klienstől, aki sajátosan kettős módon mutatja be kora Rómáját: a hibák, bünök, erkölcstelenségek és igazságtalanságok egy részét elmondja, másik részét viszont magában hordozza. Umbricius saját magát a hagyományos római értékek hordozójának állítja be, ám beszédét eközben irigység, igazságtalanság, s nem utolsósorban kirekesztő gondolatok hatják át. Az interlocutor alakja erős xenofób vonásokat hordoz, s bár e jelző gyakran magával Iuvenalisszal, illetve narrátorával kapcsolatban hangzik el, valójában csak Umbricius, a narrátorétól határozottan eltérő tulajdonságokkal felruházott fiktív beszélgetőpartnert illethetjük teljes joggal e jelzővel. ${ }^{4}$

A szöveg magyarra való átültetésekor elsődleges szempont volt Umbricius heves indulatainak, illetve (olykor csapongó és következetlen) gondolatmenetének visszaadása. Ahol lehetett, szó szerinti fordítást alkalmaztam, ahol pedig ez túlságosan magyartalan megfogalmazást eredményezett volna, ott a pontos tartalmi megfelelést tartottam szem előtt. A szöveg jegyzetelésében mértékletességre törekedtem, a tulaj-

\footnotetext{
3 A 3. szatíráról ld. részletesen GELLÉRFI (2018: 205-249) és az ott hivatkozott szakirodalmakat.
}

${ }^{4}$ Erről ld. GELLÉRFI (2019). 
donnevek többségén túl csak azokhoz a helyekhez füztem magyarázatot, melyek jegyzet híján nehezen érthető utalásokat tartalmaznak. ${ }^{5}$

\section{Felhasznált irodalom}

BRAUND 1996

COURTNEY 1980

FERGUSON 1987

GELLÉRFI 2018

GELLÉRFI 2019

MURAKÖZY 1964
S. M. BRAUND, Juvenal Satires Book I, Cambridge, 1996.

E. COURTney, A Commentary on the Satires of Juvenal, London, 1980. J. FERGUSON, A Prosopography to the Poems of Juvenal, Brussels,1987. GELLÉRFI G., Allúziós technika és müfaji hatások Iuvenalis szatíráiban, Budapest, 2018.

G. GELLÉRFI, Xenophobic Utterances in Juvenal's Satires, GraecoLatina Brunensia, 24 (2019), megjelenés alatt.

MurAKÖZY GY. (ford.), Decimus Iunius Iuvenalis szatírái, Budapest, 1964.

5 A jegyzetek írásánál COURTNEY (1980) és BRAUND (1996) kommentárjára, valamint FERGUSON (1987) proszopográfiájára támaszkodtam. 
[1] Öreg barátom távozása felkavart ugyan, mégis helyeslem, hogy az üres Cumaeba akar költözni, s így egy polgártárssal ajándékozza meg a Sibyllát. ${ }^{1}$ Baiae kapuja az, ${ }^{2}$ bájos part, kies menedék... Ami engem illet: még Prochyta is jobb, ${ }^{3}$ mint a Subura! ${ }^{4}$ Hisz találunk-e bárhol oly nyomorult, oly kihalt helyet, hogy ne tartsd rosszabbnak nála a rettegést a tűzvészektől, az állandó házomlástól, e vad város ezernyi veszélyétől és az augusztusban is szavaló poétáktól...?

[10] Ô viszont, miközben egész háztartását egyetlen szekérre pakolták, a nyirkos Capena ősi boltívei alatt álldogált. ${ }^{5}$ Hajdanán még Numa találkozgatott itt éjjeli kedvesével, ${ }^{6}$ most viszont kosarukban szénát hordó zsidók bérlik a szent forrás ligetét és templomait, minden fa köteles földbért fizetni a népnek,7 a Camenákat meg száműzték a kolduserdőből. ${ }^{8}$ Itt ereszkedtünk le Egeria völgyébe, a valóságtól elütő barlangokhoz. ${ }^{9}$ Ó, mennyivel erősebben éreznénk a víz isteni mivoltát, ha zöld növény szegélyezné habjait, s nem gyalázná márvány az őshonos tufát!

[21] Itt végül megszólalt Umbricius: „Ebben a városban már nincs helye a tisztességes mesterségeknek! A munkád nem fizetik meg, a vagyonod ma kisebb, mint tegnap, holnap meg még tovább kopik... El akarok menni innen, méghozzá oda, ahol Daedalus levetette fáradt

${ }^{1}$ A túlzsúfolt Rómához képest mindenképpen szellősebben lakott campaniai várost a többek között Aeneasnak is utat mutató jósnő székhelyeként tartották számon.

2 A népszerü fürdőhelyre, Baiaebe vezető út a félsziget bejáratánál fekvő Cumaen haladt keresztül.

${ }^{3}$ Apró, mindössze 4 négyzetkilométeres sziget (mai nevén Procida) Cumae és Baiae közelében.

${ }^{4}$ Nyüzsgő, árusokkal teli és bordélyairól hírhedt római utca és környéke - Martialis egy epigrammájában $(12,18)$ Iuvenalist a Suburában jeleníti meg.

${ }^{5}$ A dél felé tartó Via Appia a Porta Capenán haladt át, s e kapu felett húzódott az Aqua Marcia vízvezeték egyik ága, mely Martialis tanúsága szerint is $(3,47)$ csöpögött.

${ }^{6}$ A hagyomány szerint Róma második királya, Numa Pompilius itt találkozott éjjelente Egeria nimfával, aki tanácsokat adott neki.

${ }^{7}$ Alkalmasint az itt élő zsidóságra kivetett különadóra utal.

${ }^{8}$ E mondatot (12-16. sor) a szakirodalom egy része áthelyezi Egeria völgyének rövid leírása (17-20. sor) utánra.

${ }_{9}$ A hely egykori természetközeliségét a mesterséges barlangok, s a forrásvíz partjának márványborítása tették tönkre. 
szárnyait. ${ }^{10}$ Addig kell elindulnom, míg ősz hajam és öregségem újdonság, míg hátam egyenes, míg Lachesisnek van még mit kimérnie, lábaim elbírnak, s jobbom nem görnyed botra.

[29] Hagyjuk hát el hazánkat! Lakjon csak ott Artorius és Catulus, maradjanak csak azok, akik hófehéret csinálnak a feketéből, akik boldogan szerződnek bármire: legyen az templom, folyó, kikötő, csatornatisztítás, hullaszállítás, sőt akár magukat is eladják az úrlándzsa alatt. ${ }^{11}$ Egykor csak kürtösök voltak, a vidéki arénák örökös tagjai, egész városok ismerték felfújt pofájukat... Most meg ők rendeznek játékokat, s ha a csőcselék hüvelykujja úgy fordul, közkívánatra ölnek is. Aztán hazafelé menet még egy közvécét is kibérelnek, s miért is ne tennék? Hiszen Fortuna az effajtát emeli alacsony sorból a jólét magasába, ahányszor csak kedve szottyan tréfálkozni.

[41] De én mit tegyek Rómában? Hazudni nem tudok! Képtelen vagyok dicsérni egy rossz könyvet, kölcsönkérni még inkább. A csillagok járását nem ismerem, atyja temetését nem tudom és nem fogom megígérni senkinek, békabelet életemben nem vizsgáltam $!^{12}$ A menyecske másoktól kapja meg, amit nős szeretője üzen és küld, s tolvajoknak sem segítek, nem kísérek senkit, mintha béna lennék, jobbját vesztett hasznavehetetlen test.

[49] Hát itt csak a cinkost becsülik? Kinek lelkét örökké őrzendő titkok hevítik és gyötrik?! Nem lesz hasznodra, ha tisztes dologba avatnak be, ettől még senki sem érzi úgy, hogy hallgatásodért tartozna neked. Verres ${ }^{13}$ csak azt szereti, aki kedve szerint megvádolhatja! Ám az árnyékban hömpölygő Tagus összes homokja, ${ }^{14} \mathrm{~s}$ a tengerbe hordott ara-

\footnotetext{
${ }^{10}$ A Krétáról menekülő Daedalus a történet vergiliusi változata szerint Cumaenál ért földet.

11 A nyilvános árveréseken egy lándzsát tüztek ki, ez „alatt” került át a vásárlóhoz a tulajdonjog.

12 A három tagmondatot a jóslás köti össze: nem ért a korban egyre elterjedtebb asztrológiához; nem jósolja meg rokonok halálát, ami nem csupán erkölcstelen, de törvénytelen is; nem használ béljóslásra arra alkalmatlan állatokat.

${ }^{13}$ Gaius Verres, a Szicíliát kifosztó helytartó - elsősorban Cicero ellene írott vádbeszédei őrzik emlékét.

${ }_{14}$ Az Ibériai-félsziget leghosszabb folyója (ma sp. Tajo, po. Tejo), melynek aranytartalmú homokjára több antik forrás utal.
} 
nya sem érhet annyit, hogy álmatlan forgolódj, szorongva vedd fel béred, mit úgyis elszórsz, s hogy örökké tőled féljen nagy hatalmú barátod!

[58] Hogy melyik népet kedvelik a legjobban a mi gazdagjaink? Hogy kiktől menekülök különösképpen? Megmondom én mindjárt, nem röstellem! Nem bírom már elviselni, polgárok, e görög várost! Mégis mennyi jön még ide az akháj söpredékből? A szír Orontes már rég befolyt a Tiberisbe, s idehordta a nyelvet, a szokásokat, a rézsútos húrokat a fuvolással, sőt az ottani dobot is, a cirkusz mellé pedig prostituáltakat állított. Hajrá, menjetek mind, kiknek tetszik a barbár szuka meg a festett kendője!

[67] Quirinus!15 Görög cipellőben jár a parasztod! Győzelmi érem lóg viaszos nyakában! Az egyik a magas Sicyont, a másik meg Amydont hagyta hátra, ez Androsról jött, az Samosról, amaz meg Trallesből vagy Alabandából, s mind az Esquiliae meg a füzről elnevezett domb felé tart, ${ }^{16}$ hogy nagy házak mélyébe férkőzve végül urakká legyenek. Gyors elme, elvetemült vakmerőség, készséges beszéd, Isaeusénál is sodróbb. ${ }^{17}$ Mondd csak, mit gondolsz róla, ki ő? Mindenféle embert magával hozott közénk! Grammatikus, szónok, földmérő, festő, edző, madárjós, kötéltáncos, orvos, mágus - mindenhez ért az éhező görögöcske, ha úgy parancsolsz, az égbe is felmegy! Végül is nem mór volt, nem szarmata és nem is trák, aki szárnyakat öltött: ott született Athén kellős közepén!18

[81] Hát hogy ne menekülnék ezek bíborától? ${ }^{19}$ Előttem pecsételjen, s különb ágyra nehezedjen az asztalnál heverve az, kit a szilvával és a

\footnotetext{
${ }^{15}$ A római történelem korai szakaszában fontos szerepet játszó istenség, az első capitoliumi triász tagja Iuppiter és Mars mellett. Később a megistenült Romulusszal azonosították.

${ }^{16}$ A Viminalis (lat. vimen = füz) és az Esquiliae egyaránt Róma hét dombja közé tartozik.

${ }^{17}$ Asszíriai származású rétor, a Kr. u. 1. század végén érkezett Rómába, amiről ifj. Plinius $(2,3)$ is beszámol.

${ }^{18}$ A Krétáról maga építette szárnyakon elrepülő Daedalus a hagyomány szerint athéni származású volt.

${ }^{19}$ Utalás a bíborszegélyű togára.
} 
fügével együtt hozott a szél Rómába? ${ }^{20}$ Hát ennyire nem jelent semmit, hogy mi fiatalon az Aventinus levegőjét szívtuk és szabin olajbogyón nőttünk fel?

[86] Na és amikor e hízelgésben szerfölött jártas nép az oktalan beszédet és csúf barátja arcát dicséri, a vézna ember hosszú nyakát az Antaeust magasra emelő Herculesével méri össze, s csodálja a vékonyka hangot, aminél az sem rosszabb, amikor a tyúkot csipkedi az ura?! Mindezt mi is dicsérhetnénk, csakhogy nekik hisznek. Tán különb színész náluk az, aki Thaist játssza, aki feleséget alakít vagy a köpenytelen Dorist? Bizony úgy tünik, mintha nemcsak a maszk lenne nő, hanem az is, aki beszél! Azt mondanád, a hasa alatt minden sima és üres egy vékonyka réstől eltekintve. Mégsem lenne köztük különleges Antiochus, se Stratocles, se Demetrius, se a nőies Haemus: ${ }^{21}$ komikus színész az egész nép!

[100] Ha nevetsz, még nagyobb hahotázással rázkódik meg, ha barátja könnyeit látja, sír, bár nincs baja. Ha télvíz idején tüzet gyújtatsz, bebugyolálja magát, de ha azt mondod, meleged van, már izzad is. Nem vagyunk hát egy szinten: jobb nálam az, aki éjjel-nappal szüntelenül képes valaki más ábrázatát magára ölteni, mindig készen áll kezét elismerően felemelni, ha egy szépet böfögött vagy egyeneset pisilt a barátja, vagy ha reccsent egy nagyot, amikor kifordítja az arany merőkanalat. Ráadásul ágyékának semmi se szent, senki sincs tőle biztonságban: se a Lar úrnője, se szűz leányod, de még sima arcú kérője és eleddig ártatlan fiad sem. Ha pedig egyikük sem jön össze, barátja nagyanyját is hanyatt dönti. Tudni akarják a ház titkait, hogy emiatt félj tőlük.

[117] És ha már a görögöket emlegettem: hagyjuk most a gymnasiumot, hallgasd meg inkább egy nagyobb köpeny gaztettét! Egy sztoikus ölte meg Bareát, egy besúgó a barátját, egy öreg a tanítványát, kit az a part nevelt, melyre a gorgói gebe tolla hullott. ${ }^{22}$ Egyetlen rómainak sincs

20 A dokumentumok hitelesítésekor a sorrend éppúgy a társadalmi helyzetet fejezte ki, mint a lakomákon a vendégek elhelyezése.

${ }^{21}$ Görög színészek: Stratoclesről és Demetriusról - múlt időben - Quintilianus is megemlékezik (11, 3, 178), míg Haemust Iuvenalis említi 6. szatírájában (197-199). Antiochus máshonnan ismeretlen.

${ }^{22}$ Q. (?) Marcius Barea Soranust Kr. u. 66-ban ítélték el egy Nero-ellenes összeesküvésért, amihez a bizonyítékot kliense, P. Egnatius Celer szolgáltatta (ld. Tac. Ann. 16, 23- 
itt helye, ahol valami Protogenes vagy Diphilus, netán Hermarchus irányít, ${ }^{23}$ aki - népére jellemző bün ez - sosem osztozik mással a barátján, ${ }^{24}$ csakis az övé lehet egyedül. Ugyanis amikor készséges fülébe cseppent egy kicsit mérgéből, mely természete és hazája sajátja, engem kiraknak a küszöbön, odalesz a szolgaságban töltött idő... Sehol sem kisebb dolog kidobni egy klienst, mint itt!

[126] De hogy rólunk se hallgassak: a szegénynek itt miféle érdeme, miféle szolgálata lehet, még ha kész akár éjjel is togát öltve szaladni, mikor a praetor már hajtja a lictort, hogy menjen fejét leszegve, hisz a gyermektelen nők már rég felébredtek, nehogy a hivataltárs előbb köszöntse Albinát és Modiát?!25 Nemesek fiait látod egy gazdag ember szolga mellé szegődve, amaz meg Calvinának vagy Catienának annyit is megad, amennyit a tribunusok kapnak a legióban, hogy egyszer-kétszer rajtuk rángatózhasson. Te meg? Ha megtetszik egy felöltözött szajha arca, azt sem tudod, oda merd-e inteni Chionét a magas székről.

[137] Ha tanút állítasz Rómában, legyen bár oly szent, mint az idai istenség vendéglátója, ${ }^{26}$ lépjen elő maga Numa, ${ }^{27}$ vagy aki a lángoló

32 és Hist. 4, 10). Iuvenalis utalása alapján utóbbi Tarsosban tanulhatott - a mondat vége a városnév egyik lehetséges etimológiáját idézi fel, melyet a sajátosan megnevezett, Medusa véréből születő Pegasus lehullott tollából (gr. tarsos) vezetnek le. E rövid szakasz (114-118) eredetiségét olykor kétségbe vonják, mivel nem illeszkedik szervesen a szövegösszefüggésbe.

${ }^{23}$ Valószínűleg nem konkrét személyekre utal, egyszerüen jellegzetes görög nevek: „elsőszülött”; „Zeusz-kedvelte”; „Hermész-vezette”. Ráadásul a Protogenes név negatív asszociációval bírhatott a korabeli olvasó számára, hiszen Caligula egyik különösképp véreskezü embere is ezt viselte.

${ }^{24} \mathrm{Az}$ amicus („,barát”) szó hasonló kontextusban rendre a patrónust jelöli, ahogy ebben az esetben a "szolgaság” említésével Umbricius meg is világítja e kapcsolat valódi jellegét.

${ }^{25}$ A kliens-patrónus viszony fontos megnyilvánulási formája a reggeli üdvözlés (salutatio), aminek ábrázolása itt az örökségvadászattal (captatio) keveredik - ezért hangsúlyozza Umbricius, hogy egy gyermektelen nő üdvözlésére siet a praetor a lictorai felvezetésével.

${ }^{26}$ P. Cornelius Scipio Nasica, akit Kr. e. 204-ben arra jelöltek ki, hogy ő kísérje Cybele Phyrgiából érkező szobrát Rómába.

27 A bevezetőben is említett király ezúttal a tiszteletreméltóság archetipikus példájaként jelenik meg. 
templomból kimentette a rettegő Minervát, ${ }^{28}$ akkor is a vagyonát firtatják először, erkölcseit meg utoljára: »Hány szolgát etet? Mennyi földje van? Hány tálról lakomázik? Mekkorákról? « Amennyi pénzt őrzöl a ládikódban, hiteled is pont annyi van. Hiába esküszöl Samothrace ${ }^{29}$ vagy a sajátjaink oltáraira: úgy tartják, a szegény nem törődik sem az istenekkel, sem a villámaikkal, sőt mi több, ezt maguk az istenek is elnézik neki.

[147] Na és az, hogy közröhej tárgyává lesz, ha piszkos és szakadt a köpenye, mocskos a togája, egyik saruján már kirepedt a bőr, vagy ha össze is varrják e sebet, nem is egy szakadásban bukkan fel a vastag és friss szál? Semmi sem durvább ebben a nyomorult szegénységben, mint hogy nevetségessé teszi az embert. Azt mondják, hogy: »Menjen innen, ha szégyent ismer egyáltalán, keljen fel a párnáról, a lovagok helyéről mindaz, akinek vagyona ehhez a törvény szerint nem elég! Kerítők fiai üljenek ide, bármelyik bordélyban születtek is, s a kikiáltó ragyogó sarja tapsoljon itt a tollrabló gladiátor és az edző kimosakodott gyermekei között! « Erre vágyott a gőgös Otho, aki így elkülönített minket. ${ }^{30}$

[160] Melyik vő tetszett itt apósának, ha vagyona nem ért fel kedvese csomagocskájához? Melyik szegény került be végrendeletbe? Mikor fogadta be az aedilisek tanácsa? Csapatba verődve kellett volna már régen elköltöznie a szegény polgároknak innen. Sosem könnyü a felemelkedés, ha erényeidet eltakarja házad szűkös vagyona, de Rómában még keményebb a próbálkozás: sokba van a nyomorúságos szállás, sokba a szolgák hasa, és sokba a takarékos ebédke... Itt szégyen cseréptányérról enni, bezzeg ha hirtelen egy marsus vagy szabin asztalnál találnád magad, nem mondanád ezt csúfnak, s beérnéd egy durva sötétkék csuklyával. $^{31}$

[171] Az igazat megvallva, Itália nagy részében csak a halottak viselnek togát. Még a fenséges ünnepnapokon is, mikor a füves színház-

${ }^{28}$ L. Caecilius Metellus, aki Kr. e. 241-ben kimentette a Palladiumot az égő Vestatemplomból.

${ }^{29}$ Az Égei-tengerben található szigetet többek közt a kabir kultusz tette nevezetessé.

${ }^{30}$ L. Roscius Otho tribunusra utal, aki Kr. e. 67-ben a később Domitianus által felélesztett lex Roscia theatralisszal a színházakban a szenátorok mögötti 14 sor használatát a lovagi cenzushoz, azaz a vagyoni helyzethez kötötte.

31 A sötétkék csuklya a komédiában a szegények öltözéke. 
ban egy jól ismert bohózatot néznek, s a sápadt maszk szájától ${ }^{32}$ megretten a vidéki csecsemő anyja ölében, még akkor is ugyanazt a ruhát látod rajtuk, mint máskor! Sőt, ugyanazt látod a páholy nagyjain és a népen: még a nagyságos aediliseknek is elég az, hogy egy fehér tunika jelezze rangjukat. ${ }^{33}$ Nálunk viszont erőn felül ragyog az emberek ruhája, s ezért gyakran a kelleténél többet kölcsönöznek mások pénzéből. Közös bününk ez! Itt mindannyian hivalkodó-hízelgő szegénységben élünk.

[183] De mit húzzam az idődet? Rómában mindennek ára van! Mennyit fizetsz, hogy végre egyszer köszönthesd Cossust, s hogy, ha meg nem is szólal, de legalább észrevegyen Veiiento? ${ }^{34} \mathrm{Az}$ egyik az imádott ifjú szakállát nyírja, a másik a haját teszi el, a ház pedig megtelik eladó süteményekkel. ${ }^{35}$ Tessék, ez a tiéd, itt egy kis a harag-élesztő! Nekünk kell adóznunk, nekünk, a klienseknek, hogy a divatos szolgák vagyona hízzon!

[190] Ugyan ki fél, vagy félt valaha egyáltalán házomlástól a hüs Praenestében, az erdős bércek közti Volsiniiben, a szerény Gabiiban vagy a lankás Tibur magasában? ${ }^{36}$ Bezzeg a mi városunkat jórészt csak vékonyka oszlopok tartják, ezekkel dúcolja alá a gondnok, ami megdől, s miután egy régi repedés száját betömte, győzköd, hogy nyugodtan alhatunk. Közben meg inog a rom felettünk.

[197] Ott kell élni, ahol nincs tűzvész, ahol nem félsz éjjel... De Ucalegon ${ }^{37}$ már kiált is a vízért, már hordja is limlomait, már a harmadik emelet is füstöl. Te meg nem is tudsz róla! Hiszen ha az alsó szintekröl

\footnotetext{
${ }^{32} \mathrm{Az}$ ún. Fabula Atellana egyik állandó karaktere volt a nagyra nyitott szájú maszkot viselő Manducus.

${ }^{33}$ Bizonyos vidéki városokban az aedilis volt a legmagasabb tisztség.

${ }^{34}$ A rabszolgák lefizetésére utal, ami szükséges lehetett ahhoz, hogy a kliens patrónusa közelébe kerülhessen.

${ }^{35}$ Az ifjúkor elérésekor a hajvágás és az első szakállvágás rituális keretek között zajlott - itt alighanem a patrónus fiúszeretőjéről van szó. A sütemény szó az áldozati süteményeket jelöli.

${ }^{36}$ Volsinii etruriai, a másik három latiumi város, utóbbiak egyaránt üdülőhelyként is ismertek voltak.

37 Utalás Vergilius Aeneisének 2. könyvére. Ucalegon egy trójai nemes, akinek háza a lángok martalékává válik - neve a iuvenalisi kontextusban beszélő névvé válik: ouk alegón annyi mint „nem törődo””, azaz egy mások kárával nem törődő görögként jelenik meg.
} 
mindenki elfut, a legfölső fog majd megégni, melyet egyedül a tető véd az esőtől, ahol a gyönge galambok tojnak. Cordus fekhelyén Procula sem fért volna el, ${ }^{38}$ asztalát csak hat korsó ékesítette, no meg lent egy kicsike kancsóka, s a márvány alatt fekvő Chiron. Görög könyvecskéit egy ósdi kosárban őrizte, s barbár egerek rágcsálták az isteni verseket. Semmije se volt neki, hogy is tagadnánk? És a szerencsétlen még ezt a semmit is elvesztette! A csapásokat pedig az tetézi be, hogy amikor pőrén pár falatot kérne, se étellel, se tetővel, se vendégszeretettel nem szánja meg senki.

[212] Bezzeg ha Asturicus nagy háza dől le! Hajukat tépik az anyák, gyászba öltöznek a nemesek, elhalasztja a meghallgatást a praetor. Az egész várost ért csapást siratjuk akkor, gyülöljük akkor a tüzet. Még lobog a láng, s valaki már rohan is, hogy márványt adjon, hogy összeszedje a költségeket. Ez ragyogó meztelen szobrokat ad, az valami Euphranor- és Polyclitus-remekeket, egy nő ázsiai istenek régi díszeit, egy férfi könyveket, könyvtartót s középre Minervát, egy másik meg egy véka ezüstöt. Több lesz és jobb is e legboldogabb gyermektelen, Persicus kárpótlása, s már-már joggal gyanakodhatunk, hogy maga gyújtotta fel házát. ${ }^{39}$

[223] Ám ha el tudsz szakadni a cirkusztól, a legjobb házat veheted meg Sorában, Fabrateriában vagy Frusinóban ${ }^{40}$ annyiért, amennyiért most egy sötét lyukat bérelsz egy évre. Kiskert vár rád és sekély kút, melyhez kötél sem kell, könnyedén meríthetsz vizet zsenge növényeidre. Élj így, szeresd a kapát, jó gazdaként ápold kerted, melyből száz pythagoreust is bőséggel megetethetsz. ${ }^{41}$ Már az is valami, ha bárhol, bármily félreeső helyen akár csak egy gyík ura lesz belőled.

[232] Itt a legtöbb beteg a kialvatlanságba hal bele - bár magát a bágyadtságot az égő gyomorban megakadt emésztetlen étel okozza. Melyik bérlakásban lehet egyáltalán aludni? Egy egész vagyonba kerül a

\footnotetext{
38 Procula minden bizonnyal egy roppant alacsony személy - egyébként ismeretlen.

${ }_{39}$ Az Asturicus és a Persicus nevek együttes szerepeltetését egyaránt magyarázhatja az, hogy Persicus egy domus Asturicinek nevezett házban élt, de a két név ugyanazt a személyt is jelölheti.

${ }^{40}$ Latiumi városok.

${ }^{41}$ A pythagoreus tanok részét képezte a vegetarianizmus.
} 
városban az alvás, ez a betegség fő forrása. A szük utcasarkokon zörgő szekerek, s a beragadva szitkozódó hajcsár még Drusus ${ }^{42}$ és a tengeri fókák álmát is elűznék! Ha szólítja a kötelesség, már viszik is a gazdagot, a tömeg utat enged neki, az arcuk felett suhan el hatalmas csatahajóján, s közben olvas, ír vagy épp alszik odabent. A gyaloghintó bizony elringat, ha csukva az ablaka. De mégis ő ér oda előbb! Mi hiába sietünk, ha utunkba áll a hömpölygő tömeg, hátulról meg a nép egész hada nyomja a vesénk. Az egyik belém könyököl, a másik a hordszék kemény rúdjával üt meg, emez gerendával ver fejbe, amaz meg egy hordóval. Lábszáraim sártól kövérek, mindenfelől hatalmas talpak tapodnak, lábujjam egy katona csizmaszege döfi át.

[249] Ugye látod, mekkora füstfelhő ünnepli a sportulát? ${ }^{43}$ Száz vendég, mindenki nyomában saját konyhája. Még Corbulo is alig bírna el ennyi hatalmas edényt, ${ }^{44}$ ennyi mindent a fején, a szerencsétlen szolga meg nemcsak egyenes nyakkal tartja mindezt, hanem irama még a tüzet is legyezi.

[254] Szakadnak a frissen varrott tunikák, szálas ezüstfenyő billeg az érkező kocsin, pár másik szekér meg lucfenyőt hoz. Magasan bólogatnak, fenyegetik a népet. Hiszen ha elhajlik a tengely, mely a ligur köveket szállítja, s a népre borítja a hegy gyomrát, mi marad majd az emberekből? Ki talál majd testrészeket, csontokat ott? A szétzúzott holttestek úgy vesznek a semmibe, mint a lélegzet. A háznép meg mit se tud erről, mossák a tálakat, kicsiny tüzet élesztgetnek, olajvakaróktól visszhangzik a ház, a törölközőket a telt edény mellé teszik. Össze-vissza futkosnak mindezekért a szolgái, de ő már ott ül a parton, zöldfülüként borzad a rettentő révésztől, de nem remélhet fuvart a szerencsétlen az iszapos vízen át, mert senki nincs, aki egy érmét tenne a szájába. ${ }^{45}$

\footnotetext{
${ }^{42}$ Claudius császár mellékneve - Suetonius arról számol be, hogy gyakran elaludt lakomákon. A fókákat a legmélyebb álmú állatoknak tartották.

${ }^{43}$ A sportula jelentése kortól és kontextustól függően változó. Itt egyfajta közös étkezést jelöl, amelyre a kliensek összegyưlnek, szolgáik pedig hordozható tűzhelyet visznek magukkal.

${ }^{44}$ Claudius és Nero hadvezére, $\mathrm{Cn}$. Domitius Corbulo nagy termetéról Tacitus is megemlékezik (Ann. 13, 8).

${ }^{45}$ A rómaiak átvették a görög szokást, mely szerint a halott ember szájába egy érmét tesznek a holtakat az Alvilágba szállító Charon fuvardíjaként.
} 
[268] Lásd most az éjszaka számos további veszedelmét! Mily magasak a tetők, ahonnét leesve agyoncsap a cserép? Hányszor repülnek ki repedt, törött edények az ablakon? Mekkora súllyal verik kékre-zöldre, akit eltalálnak? Sőt, még a járdát is feltörik! Akár gondatlannak is tarthatnak, ha végrendelet nélkül indulsz vacsorázni, mert nem számoltál egy hirtelen „esettel”. Voltaképpen annyiszor les rád a halál, ahány nyitva virrasztó ablak alatt elmész aznap éjjel. Egyetlen kívánságod hát ez legyen, s ezt vidd magaddal szánalmas óhajként: érjék be annyival, hogy egy széles tállal nyakon öntenek!46

[278] Az arcátlan részegnek az a büntetés, ha senkivel nem akaszkodott össze: úgy szenved éjjel, mint Peleus sarja, mikor a barátját siratta, ${ }^{47}$ előbb hasán fekszik, aztán meg hanyatt. Képtelen máshogy elaludni, az ilyeneknek a perpatvar hozza meg álmát. De bármily hitvány alak is ő, kit hevít a kor s a bor, óvatosan elkerül mindenkit, akik bíbor köpenye s hosszú kísérete erre inti, főleg ha sok a fáklya s az érclámpás körülötte. Engem viszont lenéz, mert csak a hold szokott hazavezetni, vagy egy gyertya pislákoló fénye, melynek kanócát beosztom és kímélem. Halld hát e szánalmas perpatvar előhangját - ha perpatvar egyáltalán, ahol csak te ütsz, engem meg csak ütnek...

[290] Elém áll és megállít. Engedelmeskednem kell, hiszen mit is tehetsz, ha egy őrült kényszerít, aki ráadásul erősebb is. »Honnan jössz? « - kiabál. »Kinek az ecetes bora, kinek a babja püffeszt? Melyik suszterrel ettél nyesett hagymát és főtt ürüajkat? Nem felelsz? Beszélj, vagy fogadd a sarkam! Ki vele, hol a helyed? Melyik zsinagógában keresselek?« Próbálsz valamit mondani vagy meghúzod magad csendben? Egyre megy! Ugyanúgy megvernek, sőt aztán dühödten a törvény elé is rángatnak. Hogy mit szabad a szegénynek? Ha verik, kérlelhet, ha összeesett, könyöröghet, hogy hadd menjen haza legalább néhány foggal a szájában.

[302] De ne csak ettől félj! Mindig lesz, aki kifoszt majd téged, miután bezárták az ajtókat, s a tavernák kapuin már a lakat sem zörög. Néha a fürge fegyveres rabló is üzi az ipart ekkor. Ugyanis valahányszor ren-

\footnotetext{
${ }^{46}$ Minden bizonnyal az éjjeliedények utcára ürítésére utal.

${ }^{47}$ Achilleus Hektór megölését és a Patroklos tiszteletére rendezett játékokat követően forgolódik hasonlóképpen az Ilias 24. énekének kezdetén: „hol oldalán fekve, hol hátán, hol pedig arccal lefelé" (Hom. Il. 24, 10-11).
} 
det tesznek katonáink a Pomptini-mocsárban és a Gallinariafenyvesben, ${ }^{48}$ úgy szalad ide mindenki onnét, mint a vadak az etetőhöz. Hát van-e még kohó, van-e még üllő, mely nem súlyos láncot készít? Annyi vas megy el a bilincsre, hogy félö, elfogy az eke, s nem lesz majd kapa és karaszoló. Boldogok a dédapáink szépapjai, s boldognak mondhatod a királyok és tribunusok korát, amikor még egyetlen börtön elég volt egész Rómának. ${ }^{49}$

[315] Sok más okot is hozzátehetnék még, de hív a szekér, és a nap lemenőben. Mennem kell. Az ökörhajcsár már ostorát lengetve integet nekem. Ég veled, ne feledj el, és amikor csak Róma hazaenged Aquinumba pihenni, engem is hívj oda Cumaeből a Helviusok Cereséhez és a ti Dianátokhoz. ${ }^{50}$ Megyek majd csizmában a hüvös tájakra, s meghallgatom szatíráidat, ha nem szégyellik."

48 Bünözők hírhedt rejtekhelyei - előbbi mellett haladt el a Via Appia, ezért több császár is megpróbált leszámolni a banditákkal.

49 A carcer Mamertinus. A tribunusok említésével a Kr. e. 444 és 367 közötti időszakra utal, amikor létezett a tribuni militum consulari potestate (azaz „katonai tribunusok konzuli hatalommal") hivatala.

${ }^{50}$ Valószínűleg a Helvius-család egy tagja épített Ceres-templomot Aquinumban, míg Diana esetében a birtokos névmás egyaránt utalhat a család, illetve a város kötődésére az istennőhöz. 